\title{
Artificial Intelligence and the future of Human Rights
}

\begin{abstract}
Nowadays, there is no doubt about the relevance and impact of New Technologies, Predictive Algorithms, and Social Networks in the field of law. New tools such as electronic files, digitalization of documents, electronic signature, or jurisprudential and doctrinal databases are now essentials for judges, prosecutors, and lawyers.

Artificial Intelligence is being used by Government Agencies of some countries, such as the United States or Estonia, where an algorithm has replaced the work done by several civil servants. Moreover, these countries are working in the design of a robot judge capable of solving small claims through Artificial Intelligence.

Furthermore, the Internet has had an enormous impact on all aspects of our lives, and it has also enlarged the scope of crimes with a negative impact on children and teenagers, given their vulnerability and immaturity.

The purpose of the article is to address all those Technology-related subjects from a legal perspective. After this assessment, we can conclude stressing the importance of the protection of potential victims of cyber-crime and the usefulness of algorithms when delivering justice.
\end{abstract}

Keywords: Internet, Artificial Intelligence, Social Networks, Minors, Children, Teenagers, Domestic Violence, Gender Violence, Equality, Abuse, Gender, Harassment, Cyber Bullying 


\section{Social networks and gender Violence}

Among other possible definitions, we can say that online Social Networks are social structures composed ofgroups of people who share a common interest, relationship or activity over the Internet, where social gatherings take place and preferences for consumption of information are shown through real-time communication, although deferred communication can also occur. The Annual Social Media Survey for 2019 by IAB Spain(Interactive Advertising Bureau)concludes that $85 \%$ of Internet users aged 16 to 65 use Social Networks, representing more than 25.5 million users in Spain.

Under Spanish law, a restriction order consisting in the prohibition of communication with the victim, and in particular with a victim of gender-based violence, can be granted as a preventive measure in the framework ofa "protective order", Article 544.ter of the Criminal Procedure Law. This order can be also granted as apenalty (article 48 of the Criminal Code)or as a security measure under article106.1.f of the Criminal Code.

Article 468.2(d)of the Spanish Criminal Code, hereinafter CP, punishes the breach of such measures where the victim is the defendant's partner, among other persons stated in article 173.2 of the same legal instrument (the spouse of the investigated or sentimental partner even without cohabitation, the descendants, ancestors or siblings by nature, adoption or affinity, of the marriage or of the spouse or sentimental partner, minors or persons with disabilities in need of special protection who are living with them or who are subject to guardianship, care, or de facto care of the spouse or partner, or any other person integrated into the core of the family, as well as people who, because of their special vulnerability, are subject to custody or guardianship in public or 
private centers) Article468.3 punishes the person who disables or manipulates the bracelets that control the compliance with a prohibition of approximation:

\begin{abstract}
Article 468 of the Penal Code [...] 2. In all cases, a sentence of imprisonment of six months to one year, shall be imposed on those who breach a punishment of those set forth in Article 48 of this Code or a precautionary or security measure of the same kind imposed in criminal proceedings in which the victim is one of the persons referred to in Article 173.2, as well as those who breach probation measures.

3. Those who disable or disrupt the normal operation of technical devices that would have been arranged to monitor the enforcement of penalties, safety measure, or precautionary measures, do not take them with them or omit the measures required to prevent it from functioning will be punished with a fine of six to twelve months.
\end{abstract}

GUTIÉRREZ MAYO ${ }^{1}$ asks herself whether the Judge should expressly include, in these communication prohibitions, that communication through Social Media is also banned. Apparently, Article 48, which has been transcribed above, includes communication via Social Media ("by any means of communication and/or computer or telecommunication means").However, adding the phrase "including Social Networks" would add more clarity to the true scope of the prohibition, and would prevent confusion.

The offence of breaching a restriction order has important peculiarities when such a breach is committed through Social Networks, including as such WhatsApp, YouTube, Twitter, Instagram, TikTok, and Snap Chat among others. The Spanish Constitutional Court gives us the basis for resolving this issue in the Judgment of 9 October 2006, when it considered "communication"

1 GUTIERREZ MAYO, ESCARLATA. Quebrantamiento de la prohibición de comunicación a través de las redes sociales. Breaking the prohibition on communication through Social Media. 2018. Lefevre Editions. 
(in order to protect the right to secrecy of communications), as "any set of sounds or signs". This definition implies that texting an "emoji"or a "gif"is equal to communicating with words.

Prosecutor GUTIERREZ MAYO² studies whether it is possible to commit an offenceunder section $468.2 \mathrm{CP}$ by publishing a WhatsApp "status", which disappears after 24 hours. There are dissenting opinions on the issue,provided that, unless otherwise apparent, it is not in principle directed at a specific person. However, the doctrine is unanimous innoting that the offence is committed when the convicted or investigated person posts on his or her Facebook wall a message for the victim, when he or she names or tags the victim in any publication, or "likes" any of the posts in the victim's wall.

Originally, doctrine and jurisprudence limited the object of protection of this offence to the Justice Administration and excluded the victim of the restriction order, since the offence is aviolation of an injunction order, and was classified in the Code as such (this article is included in Title XX, "Crimes against the Administration of Justice").However, the most recent case law has evolved and includes in the scope of protection not only the Administration of Justice but also "the indemnity of women and other victims of crimes of gender-based violence"in the Judgment 9/2016 of the Madrid Second Instance Court of 18 January 2016, Section $29^{\text {th }}$.

On the issue, we should also highlight the recent Judgment of the Spanish Supreme Court, 72/2018 of 9 February, on sexist and terrorist tweets. These tweets read: " 53 women killed by sexist genderbased violence so far this year, few given the number of whores around that are loose","2015 will end with 56 murdered women, it is

${ }^{2}$ GUTIERREZ MAYO, ESCARLATA. Quebrantamiento de la prohibición de comunicación a través de las redes sociales. Breaking the prohibition on communication through Social Media. 2018. Lefevre Editions. 
not a good mark, but we tried hard, we'll see if we manage to double the figure in 2016 " , "I like to fuck against the stove, because I put the woman in her place twice". The judgment examined whether or not certain tweets posted on Twitter could constitute an offence of incitement to hatred of women, punishable under Article 510 of the CP. The Supreme Court upheld the sentence imposed by the Second Instance Courton the grounds that the messages did indeed originated from an arrative of hatred towards women, especially thosethat were victims of any form of mistreatment.

\section{Youth, gender violence and social networks}

The use of NewTechnologies, which is so expanded today, has a special impact on children and adolescents, usually called "digital natives." Taking advantage of this implementation of Social Networks in youth, different educational projects aimed at young audiences have been developed to promote gender equality and prevent gender-based violence ${ }^{3}$.

The aim of all these projects is to destroy the myths about gender-based violence and romantic love, and to implement an efficient and unprejudiced sexual education. Among these projects we can mention the application "Pilladaporti" of the Ministry of Health, Social Policy and Equality, which is accessible through its website, is free, and translated into six languages. In it, comic

${ }^{3}$ A. MARTOS MARTINEZ, M. M. SIMON MARQUEZ, A. B. BARRAGON MARTIN, M. M. MOLERO JURADO, M. C. PEREZ FUENTES and J. L. LINARES, Revisión del uso de las nuevas tecnologías para la intervención en violencia de género en parejas de adolescentes. Review of the use of new technologies for intervention in gender-based violence in adolescent couples. European Journal of Child Development, Education and Psychopathology, vol. 4, no. 1, 2016, pages 63-73. 
short stories are told to arouse awareness of gender inequality which are embedded in our society naturally.

This Ministry has also created an application called "Libres" aimed at victims of gender-violence, to make them aware of their status, and to help them take the necessary steps to get out of that situation. This app also informs of the resources available, and of the rights that assist them. It also offers testimonies of other girls who lived in similar situations. The download of this application is accompanied by instructions to leave no trace of navigation, and its download remains hidden on the phone, an essential feature for being used by women at risk.

Some Regional Administrations have also launched several applications to help identify situations of control in the couple, to raise awareness of gender-based violence and to promote egalitarian attitudes. For example, the Catalan Institute of Women released in 2015 a video called \#DesactivaEIControl, and two pedagogical manuals for professionals dealing with minors. The Equality Council of Ciudad Real has developed in 2016 an application called "Género ... amor?" to help detect indicators of violence through anonymous questionnaires and the Canary Equality Institute has created an app called "SMS Amor 3.0" to promote egalitarian attitudes, among other Regional Administrations.

The myth of romantic love is one of the main reasons why young women do not know or have difficulty in identifying attitudes that are constitutive of low-intensity gender violence, confusing them with acts of love. We are referring to so-called microsexism, that is, small gestures, imposed limits that are confused with selfimposition, control, or humiliation, and which due to this filter of "romantic love" or "he does it because he loves me" permeate the sentimental relationship blurred by a romantic vision of domination which is mistakenly perceived as love or an instinct of protection. 
According to Professor HERRERA (2009) romantic love is a collective emotional utopia, or a feeling totally idealized by society, which is used as a mechanism to calm the fear of confronting life and loneliness. This idea of romantic love is associated to happiness and self-realization and is seen a way to escape loneliness and/or feel strong emotions. The main problem is that this idea does not originate from an egalitarian approach, but generally from an emotional dependence on the other person who is supposed to be complementary and necessary to selffulfillment(the so-called "my better half"), and especially from the dependence of women on men: The patriarchal system educates us, women, to be complementary beings of another: partner, family, etc... ${ }^{4}$ Some authors have highlighted the gravity and ill consequences of perpetuating these ideas which are so harmful to gender equality, maintained through songs, films, novels, advertising, etc: However, we believe it [romantic love] has a fundamental role in the maintenance and perpetuation of the social subordination of women and that, in addition, it may have a direct and crucial importance to provide alternative points of view on current issues such as, for example, violence against women ${ }^{5}$.

${ }^{4}$ M. A. BLANCO RUIZ, Implicaciones del uso de las Redes Sociales en el aumento de la violencia de género en adolescentes. Implications of the Use of Social Networks in the increase of gender-based violence in adolescents. Communication and Media No. 30 (2014) ISSN 0719-1529, Institute of Communication and Image. University of Chile, 2014, pages 124-141.

5 M. L. ESTEBAN GALARZA, R. MEDINA DOMÉNECH, A. TÁVORA RIVERO, ¿Por qué analizar el amor? Nuevas posibilidades para el estudio de las desigualdades de género. Why analyze love? New possibilities for the study of gender inequalities. (2005) In: DíezMintegui, C.; Gregorio Gil, C. (coord.) Cultural changes and gender inequalities in the current local-global framework. $X$ Congress of Anthropology. Seville: FAAEE-Fundación EI MonteASANA

European Ethical Charter on the use of Artificial Intelligence in Judicial Systems and their environment (Council of Europe)

2005, pages 207-223. 
Professor BAKER MILLAR $^{6}$ has stated that women are continually encouraged in our society to create and maintain relationships in a way that the need for attachment becomes one of the main motivations determining our lives. Feelings of guilt, fear of the process of individualization and loneliness contribute to the validity of alienating love. In this way, there is a situation of conflict in women between attending to one's desire or attending to the wishes of the other; between building a more individualized identity as subjects with desires, initiatives and capacity for action, and being the object ofdesire for men (in heterosexual women), which takes them away from the position of subjects and returns them to the position of objects ${ }^{7}$. Such conflict can produce not only dissatisfaction but even health problems, such as anxiety or depression, hence the importance of dismantling these myths and enhancing equality from an early age, because from a young age we receive constant messages of what a girl and a boy should be. Girls are expected to be pink princesses in search of a Prince Charming, and boys are expected to be men of action. Regarding teenagers, there is a wide range of love-based series and films, which convey the idea that love justifies everything, providing legitimacy to the love-suffering binomial.

The implementation of Social Media makes online violence more subtle, more unnoticed, and more constant. A study ${ }^{8}$ of

6 J. BAKER MILLAR, Toward a New psychology of women. Beacon Press. Boston. 1987.

${ }^{7}$ A. HERNANDO, Power, individuality and female gender identity. In: Poder, individualidad e identidad de género femenina: ¿Desean las mujeres el poder? Do women desire power?, Minerva Editions, 2003, pages 71-136.

8 M. A. BLANCO RUIZ, Implicaciones del uso de las Redes Sociales en el aumento de la violencia de género en adolescentes. Implications of the Use of Social Networks in the increase of gender-based violence in adolescents. Communication and Media No. 30 (2014) ISSN 0719-1529, Institute of Communication and Image. University of Chile, 2014, page 132. 
students aged 13 to 18, from the 2012/2013 academic year in Spain, showed that most of them agreed with the myth of the better half (there is a person destined to be our partner), eternal passion (the passion of the first days must always last in true love), omnipotence (love can everything) and jealousy (the control of the couple is a sign of love and protection)

\section{Internet risks for minors}

The use of New Technologies by children and adolescents is somewhat innate in them because they were born in a generation in which they were already implemented, in the "network society". Teenagers use them to relate to others and it is an essential tool in school activity. There are authors, such as LORENTE LAPEZ ${ }^{10}$ who claim that children do not surf the Internet for a service like adults do, but that they "are" on the Internet, they use it to study, to communicate with their friends, to listen to music, to watch TV, to play, to learn, to share images, to know places. However, the fact that the Internet is well-known by them does not mean that it no longer entails risks. There is a whole series of offences born from the use of the Internet, which have minors as their victims because of their greater vulnerability, innocence and ignorance. These can be classified as follows:

A. Cyber-bullying can be defined as peer bullying using electronic means and often involves repeated offensive messages, spreading cruel or damaging rumors, posting personal data,

9 M. CASTELLS, The Theory of the Network Society. 2016. Polity.

10 Ma. C. LORENTE LAPEZ,. La vulneración de los derechos al honor, a la intimidad y a la propia imagen de los menores a través de las Nuevas Tecnologías. The violation of the rights to honor, privacy and the self-image of minors through New Technologies. Aranzadi Doctrinal Journal No. 2/2015, part Studies. Editorial Aranzadi SAU. Cizur Minor. 2015. 
theft of passwords, impersonation, recording of beatings and subsequently disseminating them (also known as Happy Slapping, which consists of recording aggressions or humiliations and then spreading them, presenting the victim in a comical and ridiculous way), etc. It may also consist of morphing which is the dissemination in the Internet of the distorted and manipulated image of the minor with sexual or vexatious connotations.

The behaviors that may constitute cyber-bullying are varied and depend on both the computer expertise of the perpetrator and/or the means at his or her disposal. In any case, these are common elements to all of them: a) a computer is used, b) the consequences are volatile, that is, they can easily disappear, c) each specific fact will require a different investigative effort depending on the computer complexity used, and d) it is common for the perpetrator to use a third party device to commit the crime, without the consent of its owner ${ }^{11}$.

This conduct could be subsumed in article 197 of the Spanish Penal Code, which punishes anyone who discloses information to third parties without the consent of the owner, with express provision when the victim is a minor. However, there is also a sector of the Spanish Public Prosecutor's Office that believes that these conducts are offences against moral integrity, from articles 173 and onwards of the Penal Code, which punishes the person who give another person degrading treatment, seriously undermining their moral integrity, because the purpose of the action is to attack the dignity of the person and embarrass him or her.

11 Ma E. SAAVEDRA MONTERO, Delitos informáticos y menores. Computer crimes and minors. Digital Training Notebooks No. 37 (2015) of the General Council of the Judiciary, 2015. 
One type of cyber-bulling is dating violence or violence between young couples via Social Media, where the chances of continuously controlling the victim are much higher and can lead to gender-based violence in adults ${ }^{12}$.

B. The importance of the image itself is often underestimated by teenagers, so that they upload their images on the Internet without being aware that they are thus losing control over them. This lack of awareness has promoted a type of extortion called sexting consisting in the threat of disseminating images of the child with erotic or pornographic content to get something in exchange from him or her. The consequences of these events can have worldwide effects and severely affect the child's future reputation and "digital biography"13

C. We can also highlight child grooming in which an adult, posing as a minor, contacts another minor through Social Networks, earns his or her trust to subsequently make an appointment with him or her for sexual purposes or to obtain images of them with erotic or pornographic content. If the teenager refuses to do so, a phase of threat and harassment usually begins, in which the harasser blackmails the child under the threat of spreading the images or telling his or her parents if he/she does not comply with what he is demanding. Article 183.ter of the Spanish Penal Code as drafted by LO 1/2015,punishes this conduct and provides:

12 F. J. BIURRUN ABAD, Los riesgos de las Nuevas Tecnologías en los menores. The risks of new technologies in minors. Legal News Aranzadi No. 921/2016. Opinion. Editorial Aranzadi SAU, Cizur Minor, 2016.

${ }^{13}$ A. RALLO LOMBARTE, A partir de la protección de datos. El derecho al olvido en Internet. Privacy in the digital age: the right to be forgotten. Aranzadi Legal News, No. 815/2011. Tribune, 2011. 
1. Anyone who, through the Internet, telephone or any other information and communication technology, contacts a child under the age of sixteen and proposes to arrange a meeting with him or her in order to commit any of the offences described in Articles 183 and 189 , provided that such a proposal is accompanied by material acts aimed at rapprochement, he or she shall be punished by the penalty of one to three years' imprisonment or a fine of twelve to twentyfour months, without prejudice to the penalties corresponding to the offences if any committed. Penalties shall be imposed in their upper half where the rapprochement is obtained through coercion, intimidation, or deception.

2. Anyone who, through the Internet, telephone or any other information and communication technology contacts a child under the age of sixteen and performs acts aimed at tricking him or her to provide pornographic material with images of who appears to be a minor, will be punished with a prison term of six months to two years.

D. Finally, we will refer to the phenomenon of Instamoms or Instadads, who are all those "parents who, without being public figures, have accounts with a public profile on Social Networks, mainly on Facebook, Instagram and YouTube, in which they upload daily multiple images and/or videos of their underage children. Many of these publicly profiled accounts have hundreds of thousands and even millions of followers and their holders receive gifts and money from brands for displaying on such Social Networks those products in the daily lives of their younger children, becoming the main source of income of their creators"14.

We are not talking about a parent who uploads an image of his or her children on Social Media, but who, constantly and generally for profit, expose images of their children on their

14 E. GUTIERREZ MAYO, and J. L. ORTEGA CALDERON, Análisis penal y procesal del fenómeno de las instamamis. Criminal and procedural analysis of the phenomenon of the Instamoms. El Derecho.com, 2017. 
daily activities, even the most intimate, such as those related to them suffering diseases. Disseminating these images for economic purposes clearly and severely undermines the honor and reputation of minors and is contrary to their interests, so the consent of the parent who uploads the image is not valid and should be understood to be non-existent. In addition, the exposure of minors on Social Media subjects them to public comments, which can be offensive.

The dissemination of certain images and videos of children on Social Networks can not only undermine the privacy of minors, but can also affect their moral integrity. We refer to images of naked children (when changing clothes, bathing them, in the pool, etc.) as well as when parents narrate in detail the diseases their children suffer accompanied by images and videos, even in the hospital.

In the opinion of some legal experts on doctrine, this conduct that we have just described would fit into the types of article 197.7 and 173.1 of the Penal Code to which we will subsequently refer; however, in the Conclusions of the Sixth Conference of Specialist Prosecutors against Computer Crime, held in February 2017, the following sixth conclusion is reflected:

"In recent months, it has been detected a progressive increase of publishing intimate images and content related to young children by certain parents through Social Networks and other internet forums. Those actions that, while devoid of criminal character, can affect the normal development and personal evolution of the children thus represented. Concerned about this fact, and the consequences that may arise for the child affected by such publications, it is agreed that, in the event of requesting the provisional or definitive withdrawal of such cases, should be asked the appropriate transfer to the territorial service of the Child Prosecutor's Office so that they can assess the possible adoption of measures they deem appropriate for the proper protection of the child" 
In other words, such conduct does not fit any of the offences in the Spanish Penal Code, without prejudice to the fact that measures could be taken in the civil jurisdiction for the protection of such minors.

\section{The robot judge}

The project of a robot that is able, through Artificial Intelligence, to resolve small claims through algorithms is a reality in some countries. Proponents of this project emphasize that this eliminates the subjective aspects that can affect decision-making, making a judge truly impartial. Artificial Intelligence can be defined ${ }^{15}$ as the process by which a computer is able to perform tasks that, when performed by a human being, requires reasoning. The issues posed by this robot judge is who programs it, that is, and under what ethics the algorithm is built, because the programmer himself or herself can incorporate his or her own discriminatory biases even unconsciously. This was the case with Tay, a conversation botcreated by Microsoft for Twitter in 2016, under the username @TayandYou (a bot is a computer program that automatically performs repetitive tasks, whose realization by a person would be impossible or very tedious). This bot was able, through Artificial Intelligence, to respond to Tweets and to make Internet memes. After only a day of operation, Twitter users intentionally got Tay to send racist and sexual messages.

Furthermore, it is not suitable for interpreting complex issues that may arise in the apparently simpler claim, or for fixing the

${ }^{15}$ F. TRAZEGNIES, 2013, ¿Seguirán existiendo jueces en el futuro? El razonamiento judicial y la inteligencia artificial. Will there still be judges in the future? Judicial reasoning and Artificial Intelligence. Revista lus et Veritas no 47, December 2013. ISSN 1995-2929, page 115. 
facts declared as proven. We must bear in mind that words used in law do not always have a unique meaning and must be interpreted in accordance with the social reality in which they are to be applied which is unknown to the expert system. The letter of the contracts has a number of rules for their interpretation in the light of the previous and subsequent acts of the parties, and even the joint interpretation of the entire contract is possible under Spanish law. However, we must recognize that the use of expert systems can offer us great help when seeking jurisprudential references, insofar as it does not impose a particular solution on us, does not tend to replace the judge but serves as a tool. The expert system is both a safety stick for the intellectual walker of law and a demand to walk more and more daringly, a support of the judge's reasoning and a challenge to his intellectual capacity ${ }^{16}$.

One of the first "expert systems" to be developed was MYCIN in the field of medicine. It was developed by Stanford University in the 1970s, to help diagnose and treat meningitis and bacteriological infections in the brain. In the United States, the COMPAS algorithm(acronym for Correctional Offender Management Profiling for Alternative Sanctions) is used in the Criminal Courts of the State of Wisconsin to estimate the degree of danger and risk of recidivism, which is accused of discriminating against the AfricanAmerican collective. Worth to be mentioned are: the PATTERN system (which was developed to assess federal parole decisions in the USA) and Arnold Foundation's Public Safety Assessment, an algorithm for bail decisions which considers several factors to deliver its decision (which is not binding for the judge): the

16 F. TRAZEGNIES, ¿Seguirán existiendo jueces en el futuro? El razonamiento judicial y la inteligencia artificial. Will there still be judges in the future? Judicial reasoning and Artificial Intelligence. Revista lus et Veritas no 47, December 2013. ISSN 1995-2929, page 128. 
defendant's age, the current violent offence, pending charges at the time of the offence, prior misdemeanour, felony and violent convictions, prior failure to appear in the past two years and prior sentences to incarceration ${ }^{17}$.

Buchanan and Headrick were pioneers in studying the application of Artificial Intelligence to law in the work "Some speculation about A.I. reasoning", in which they investigated whether legal reasoning can be carried out by a computer and they open up four areas: searches in legal and jurisprudential databases, document management and writing, formulation of opinions, and case resolution and elaboration of theories, dogmas and legal systems.

After this first attempt, other projects have been developed; however, none of them has achieved a relevant practical result. We can mention the expert system developed by the Massachusetts Institute of Technology to establish liability for assault and battery injuries ;the JUDITH system created by Walter G. Popp and Bernhart Schlink, which could apply the German Civil Code; and the HYPO system created to analyze cases of trade secrets, so that, when the data of a particular case are entered, it is able to return a list of similar cases for the defense or for setting grounds for the judgment. Some researchers in the USA use algorithms to attempt to predict courts' decision using the Supreme Court database with an accuracy of about $75 \%{ }^{18}$.

In the case of Spain, there is the Comprehensive Monitoring System in cases of gender-based violence, VioGén. This system

17 . COGLIANESE, M. LAVI, B.D. Al in Adjudication and Administration. University of Pennsylvania Carey Law School. Penn Law: Legal Scholarship Repository, 2020.

18 MATTHEW HUTSON, Artificial Prevails at Predicting Suprem Court Decisions, SCIENCE, 2017. 
assesses the risk of violenceagainstwomenand becameoperational on July 26, 2007, in compliance with the provisions of Organic Law $1 / 2004$, of December 28, on Comprehensive Protection Measures against Gender Violence. In addition to this objective, the System also aims to agglutinate the different institutions with competences in the field of gender-based violence, integrate all information of interest, monitor and protect victims throughout the national territory and prevent, issuing warnings, alerts and alarms, through the "Subsystem of Automated Notifications" when an incident or event is detected that may jeopardize the integrity of the victim.

VioGénoperates based on a template filled by the Police Officers (not by the victims) in charge of the investigation and the protection of the victims. The template must be completed with all the information collected by the investigator: the information provided by the victim, the author himself, other persons involved (relatives or neighbors), other services (police databases), and those contained in reports or documents (i.e.: the technical site visit, medical parts of injuries, or reports of the Social or Psychological Services) $)^{19}$.

These templates are completed exclusively online(there are no paper versions) through the VioGénSystem, so that the mathematical algorithms can operate and provide the police officer with an automatic result of the risk for the victim, which the officer can subsequently confirm or modify according to his or her experience and knowledge the case.

The system has undergone various revisions and improvements since it came into operation, starting on the basis

19 J. L. GONZALEZ, J. J. LOPEZ OSSORIO, M. MUÑOZ RIVAS, La valoración policial del riesgo de violencia contra la mujer pareja en España - Sistema VioGén. Police assessment of the risk of violence against female partners in Spain - VioGén System (2018) Ministry of the Interior, Page 110. 
of unstructured professional judgment (clinical judgment), passing through an actuarial model, and ending in a semi actuarial system that uses static and dynamic indicators (risk and protection). The VioGén System has its own algorithm and is able to evaluate the probability of recidivism. The Police Risk Assessment template consists of 43 indicators, 34 are risky and 9 are protective. The form includes an indicator aimed at knowing the victim's perception of her own risk, although, after recording the victim's response, the police officer must establish to what extent the victim may be undervaluing her risk. This allows police officers specialized in victim protection to contribute to the victim better adjusting her perception of risk and her better self-protection through an interview $^{20}$.

Finally, at European level, we must point out that the relationship between Artificial Intelligence and Justice is one of the Council of Europe's concerns, and more specifically one of the European Commission for the Efficiency of Justice's objectives. This body has published the "European Ethical Charter on the use of Artificial Intelligence in Judicial Systems and their environment", in which it recognizes its increasing importance in modern society and establishes five fundamental principles for its application:

1. Principle of respect for fundamental rights: ensure that the design and implementation of artificial intelligence tools and services are compatible with fundamental rights.

2. Principle of non-discrimination: specifically prevent the development or intensification of any discrimination between individuals or groups of individuals.

20 J. L. GONZALEZ, J. J. LOPEZ OSSORIO, M. MUÑOZ RIVAS, La valoración policial del riesgo de violencia contra la mujer pareja en España - Sistema VioGén. Police assessment of the risk of violence against female partners in Spain - VioGén System (2018) Ministry of the Interior, Page 61. 
3. Principle of quality and security: with regard to the processing of judicial decisions and data, use certified sources and intangible data with models elaborated in a multi-disciplinary manner, in a secure technological environment.

4. Principle of transparency, impartiality and fairness: make data processing methods accessible and understandable, authorise external audits.

5. Principle "under user control": preclude a prescriptive approach and ensure that users are informed actors and in control of the choices made.

\section{Conclusions}

Internet is a potential risk for minors; therefore, it requires efficient protective measures and an educational program integrated into the school systems.

Gender violence can be exercised through New Technologies as a means of control and harassment. Consequently, the information provided to victims to self-protect themselves should be intensified, as well as including new crimes in the Criminal Code to avoid impunity for certain behaviors.

In the current state of science, it cannot be assert that a robot judge can offer a fair trial due to the possibility of being intentionally manipulated in order to obtain an specific judgement. Nevertheless, the algorithms used in law can be a great source of help for judges, prosecutors, and police officers due its capacity of processing and classifying data. 


\section{References:}

Annual Social Media Survey 2019 by IAB Spain (Interactive Advertising Bureau)

BAKER MILLER, J. Toward a New psychology of women. Beacon Press. Boston. 1987. ISBN 978-08-0702-958-9.

BIURRUN ABAD, F.J. Los riesgos de las Nuevas Tecnologías en los menores. The risks of new technologies in minors. Legal News Aranzadi No. 921/2016. Opinion. Editorial Aranzadi SAU, Cizur Minor (2016)

BLANCO RUIZ, M.A., Implicaciones del uso de las Redes Sociales en el aumento de la violencia de género en adolescentes. Implications of the Use of Social Networks in the increase of gender-based violence in adolescents. Communication and Media No. 30 (2014) ISSN 0719-1529, Institute of Communication and Image. University of Chile.

CASTELLS, M., The Theory of the Network Society. (2016). Polity. ISBN 978-074563 2773.

COGLIANESE, C.; LAVI M., B.D. Al in Adjudication and Administration. University of Pennsylvania Carey Law School. Penn Law: Legal Scholarship Repository (2020)

ESTEBAN GALARZA, M.L.; MEDINADOMENECH R.; TÁVORA RIVERO

A. ¿Por qué analizar el amor? Nuevas posibilidades para el estudio de las desigualdades de género. Why analyze love? New possibilities for the study of gender inequalities. (2005) In: DíezMintegui, C.; Gregorio Gil, C. (coord.) Cultural changes and gender inequalities in the current local-global framework. $X$ Congress of Anthropology. Seville: FAAEE-Fundación EI MonteASANA

European Ethical Charter on the use of Artificial Intelligence in Judicial

Systems and their environment (Council of Europe)

GONZALEZ ALVAREZ, J.L., LOPEZ OSSORIO J.J., MUÑOZ RIVAS, M. La valoración policial del riesgo de violencia contra la mujer 
pareja en España - Sistema VioGén. Police assessment of the risk of violence against female partners in Spain - VioGén System (2018) Ministry of the Interior.

GUTIERREZ MAYO, E. and ORTEGA CALDERON J.L. Análisis penal y procesal del fenómeno de las instamamis. Criminal and procedural analysis of the phenomenon of the Instamoms. El Derecho. com (2017) https://elderecho.com/analisis-penal-y-procesal-delfenomeno-de-las-instamamis

GUTIERREZ MAYO, ESCARLATA. Quebrantamiento de la prohibición de comunicación a través de las redes sociales. Breaking the prohibition on communication through Social Media. 2018. Lefevre Editions.

HERNANDO, A. Power, individuality and female gender identity. In: Poder, individualidad e identidad de género femenina: ¿Desean las mujeres el poder? Do women desire power?, Minerva Editions. (2003) HERRERA, C. La construcción sociocultural de la realidad, del género y del amor. The sociocultural construction of reality, gender and romantic love. Thesis Carlos III University of Madrid. https://dialnet. unirioja.es/servlet/tesis?codigo $=180293$

https://elderecho.com/quebrantamiento-de-la-prohibicion-decomunicacion-a-traves-de-las-redes-sociales https://www.sciencemag.org/news/2017/05/artificial-intelligenceprevails-predicting-supreme-court-decisions

HUTSON, M. Artificial Prevails at Predicting Suprem Court Decisions, SCIENCE (2017)

LORENTE LAPEZ, Ma. C. La vulneración de los derechos al honor, a la intimidad y a la propia imagen de los menores a través de las Nuevas Tecnologías. The violation of the rights to honor, privacy and the self-image of minors through New Technologies. Aranzadi Doctrinal Journal No. 2/2015, part Studies. Editorial Aranzadi SAU. Cizur Minor. 2015 
MARTOS MARTINEZ, A., SIMON MARQUEZ, M.M., BARRAGON MARTIN, A.B., MOLERO JURADO M.M., PEREZ FUENTES, M.C. and G.C. LINARES, J.L. Revisión del uso de las nuevas tecnologías para la intervención en violencia de género en parejas de adolescentes. Review of the use of new technologies for intervention in genderbased violence in adolescent couples. European Journal of Child Development, Education and Psychopathology, 2016, vol. 4, no. 1

RALLO LOMBARTE, A. A partir de la protección de datos. El derecho al olvido en Internet. Privacy in the digital age: the right to be forgotten. Aranzadi Legal News, No. 815/2011. Tribune. (2011)

SAAVEDRA MONTERO, Ma E. Delitos informáticos y menores. Computer crimes and minors. Digital Training Notebooks No. 37 (2015) of the General Council of the Judiciary.

TRAZEGNIES de, F. ¿Seguirán existiendo jueces en el futuro? El razonamiento judicial y la inteligencia artificial. Will there still be judges in the future? Judicial reasoning and Artificial Intelligence. Revista lus et Veritas no 47, December 2013. ISSN 1995-2929. 